Izlaganje sa skupa UDK 1:615.851(045)

doi: $10.21464 /$ fi39101

Primljeno: 12. 12. 2018.

\author{
Theodor Itten \\ Psychotherapeutische Praxis Theodor Itten, Magniberg 10, CH-9000 St. Gallen \\ info@ittentheodor.ch
}

\title{
Nova Politika doživljaja i R. D. Laingove stare »nove ideje«
}

\begin{abstract}
Sažetak
U članku se istražuje psihoterapijsko nasljeđe R. D. Lainga i njegovo novo shvaćanje škotske psihodinamske psihijatrije, u sklopu čije ostavštine je prakticirao koncept - »pacijent je kao ja $i$ ti«. Kritički ću evaluirati njegovo iskustveno svjedočanstvo psihoanalitičara $i$ teoretičara unutar polja tzv. "antipsihijatrije«, "radikalne psihijatrije" $i$ »avanti-psihijatrije», obilježenog gnjevom i bijesom usmjerenima prema bezličnoj prirodi moderne psihijatrije, malignih utjecaja farmaceutske industrije, otuđujućeg karaktera suvremenog sveučilišnog obrazovanja - čimbenika prisutnih od sredine 1960-ih do kasnih 1980-ih. Fokus Nove politike doživljaja, usmjeren na radikalno društveno razmišljanje i interdisciplinarno istraživanje, temelji se na društvenim fenomenološko-empirijskim istraživanjima i razvoju integrativnog psihoterapijskog pristupa.
\end{abstract}

\section{Ključne riječi}

Ronald David Laing, aporije psihe, Nova politika doživljaja, integrativna psihoterapija

Za koga se bavimo drugima ili brinemo o njima? Kao pacijenti, kome se obraćamo kada više ne znamo kamo ići? Molim, dopustite da ovo temeljno pitanje utone $u$ vas i dozvolite si trenutak za razmisliti o svom odgovoru i zabilježite ga da biste se mogli sjetiti kada dođe vrijeme da ga stavite u akciju. U društvenom smo kontekstu uvijek većma aktivni, a krucijalno je pitanje tko može učiniti što, u čije ime i zašto? Ta su pitanja iznijeli radikalni (korijenu nahodeći) psihijatri iz 1960-ih, koje su kasnije prozvali, ponekad u pozitivnom, a ponekad u negativnom kontekstu - »antipsihijatri«. Zapravo, antitetični spram iscjeljivanja duše u tim su dobrim starim vremenima bili tradicionalni medicinski psihijatri sa svojim medicinskim i genetskim modelima. Anti-pokreta bilo je mnoštvo, poput anti-autoritarnog obrazovanja; anti-baby-pilula; anti-psihotika; protiv rata u Vijetnamu; anti-anti-anarhije. Dakle, kada je doktor David Cooper, kolega psihijatar Ronalda Davida Lainga, objavio svoju malu knjigu Psihijatrija i antipsihijatrija 1967. godine, ova je scena lansirana s nepoznatim odredištem. Ipak, ovdje smo da bismo se brinuli za »aporiju«, a ne za »anti«.

\section{Aporia}

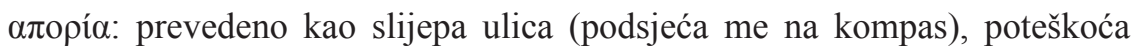
prolaženja ili težak životni prolaz, ponekad čak i nedostatak snalažljivosti (podsjeća me i na samoosnaživanje) koju Sokrat, barem u svojim filozofskim 
dijalozima, označava stvorenim stanjem zbunjenosti pokrenutim njegovim lukavim pitanjima. Ne postajemo li toga svjesni, izuzev naše grčko-hebrejske baštine, čitanjem Zen Koansa, primjerice: što vidite u praznom ogledalu? Ili za nas: kamo idemo kada ne znamo kamo ići? Ili: što da radimo, kada ne znamo što učiniti? Samo počuj trenutak mogućeg odgovora u sebi i zapamti ga, molim te. Psiha, kao što svi znate, grčka je riječ za »dah života« ili »životni dah «. Kao što je istinsko ja (maska) koja nas čeka u smrti, kada naš posljednji zemljani dah premine u Sve-u-jednom. Ne čini li sve ovo filozofsko promišljanje jednostavnim? Da? Međutim, to je daleko od lakog shvaćanja, a još je kompleksnije za provođenje u praksi, zar ne?

Naše Sebstvo podijeljeno je na barem dvije, ako ne i više strana, umjesto da biva jedinstvenim. Živimo i bivamo življenima. Uvijek postoji više za jednoga, koje volimo nazivati Svjesno - koje je sadržajno maleno u odnosu na veliko, da ne kažemo neizmjerno - Nesvjesno. Jedna od životnih zadaća jest uravnotežiti mnoge-u-jednom pojedincu, i pojedinca-u-mnogima, da bismo bivali jednim od pripadnika vrste Homo sapiens. Moj bivši učitelj antropologije i dugogodišnji prijatelj Francis Huxley (1923.-2016.) završio je svoju očaravajuću knjigu Put Svetog (1974.) sljedećim rečenicama, tvrdeći da zen budisti sugeriraju da na vječno pitanje »Što sam ja? « može odgovoriti jedino - »To si ti«. Huxley piše:

»To je tajna Svetog u jednoj točki. To je, kako kaže Ananda Kentish Coomaraswamy (1877.1947.), teologija i autologija - znanost o načelu koje svaki muškarac i žena naziva 'ja' - dokazujući isto. Jer kao što postoje dva u vječnom - što se može vizualizirati kao Boginja ili Bog, kako god vam se sviđa - koji je istovremeno i ljubav i smrt, tako postoje, kao što sve tradicije jednoglasno potvrđuju, dvoje u nama; premda ne dvije nje ili njega i nas dvoje, čak ni jedan od nje ili njega ili jedan od nas, već samo jedan od oboje.« (Huxley 1974, 328)

U nedavnom snu, prošao sam kroz mali i uski ulaz u unutrašnjost zemlje, slijedeći starog momka ispred mene. Hodajući iza njega, shvaćam da je to Ronald David Laing (1927.-1989.) koji napamet zna mjesto ulaza i put do dna rudnika. Na ulazu, u blagom sjaju drveta, zatražio je moju žutu baklju koju sam mu spremno posudio. Slijedim njegove stope. Na početku je ulazni tunel zbijen i zastrašujuće uzak. Jednom kad se spustimo niz dugačke krivudave stube, starac mi dodaje ravnu lopatu. Tiho mi pokazuje radeći ono što su mnogi rudari učinili prije njega i mene. Nježno gurnite lopatu nekoliko centimetara u zemlju ispunjenu bakrom, a zatim je prebacite u sito. Ovo je spor rad. Dublje kopanje i time propuštanje bakra u unutrašnjosti zemlje čini ovaj vitalni materijal dostupnim za legure kositra i cinka. Ovdje su legure slike iz snova, promatrane kroz (dijagnozu), a ne samo promatrane i zrcaleće, dok ideal postaje stvaran u svakodnevici. Mi ljudi snop smo navika i osobitosti koje su se spojile bez pomoći središnje organizacijske sile. Strukturna antropologija već neko vrijeme promišlja ovo pitanje navike istinskog i lažnog Sebstva. Ako smo u pravom Sebstvu, jesmo li zapravo mentalno zdraviji? Da. Možemo izabrati, ako to želimo, ali ne moramo jer smo uvijek na obje strane naše životinjske prirode. $\mathrm{S}$ jedne strane, mi smo visoko razvijeni i kultivirani primati. S druge strane, ljudska bića koja smo postali razvila su sposobnost razmišljanja o kulturi naše vlastite prirode. Francis Huxley, koji je jednom prilikom Lainga opisao kao demistifikacijskog »mistifikatora«, jasno kaže:

»Sâmo sveto očito je misterij svijesti, koristeći svjetsku tajnu ne da označi problem koji se može intelektualno riješiti, već proces buđenja i transformacija koja se mora odigrati kako bi se iskusila, a biva iskušena se ako se želi učiniti vlastitim.« (Huxley 1974, 31) 


\section{Ludilo je intencionalno}

Jedan od Laingovih poznatih mota bio je: »Ništa ljudsko ne smatram stranim«. U ludilu se doživljava nešto intencionalno. To kretanje duše ili psihe podrazumijeva temperamentnu aktivnost s osobom, što tijekom tog procesa često djeluje zbunjujuće. The Divided Self, kako ga je R. D. Laing razumio, otpočinje slikom unificiranog Jastva, onog personificiranog. Njegov klinički rad, primjeri koji su u njegovoj prvoj knjizi predstavljeni kroz devet slučajeva, a završeni 1957., provedeni su u bolnici Gartnavel Royal u Glasgowu. Zajedno s J. L. Cameronom, A. McGhiejem i medicinskim sestrama vodio je »Rumpus Room Experiment « (Cameron i sur., 1955). Njihov osnovni aksiom bio je: tretirati takozvane »lude« ljude na isti humani način kao što se odnosimo jedna prema drugima. S vremenom, njihove društvene interakcije i komunikacije ponovno se približavaju normalnosti. Nakon 38 godina iskustva u umjetnosti i znanosti o iscjeljenju, 61-godišnji Laing rekao je:

»Postoji asimetrija u sobi u kojoj me druga osoba potražila poradi onog zbog čega me želi vidjeti. No ja nisam zatražio da ih vidim, te zarađujem za život od ove aktivnosti. Psihoterapija: ona podrazumijeva davanje pozornosti i dostupnost nečije prisutnosti. Slušanje na prvom mjestu težak je posao (...). Mnogi ljudi koji su me došli posjetiti rekli su da je glavna stvar koju su od mene dobili to što ih slušam (...). Ako su došli vidjeti nekoga tko ih zapravo vidi i čuje i doista prepoznaje njihovu stvarnost, svoje postojanje, to je samo po sebi oslobađajuće (...). Imali su moje društvo i pažnju, moj angažman usmjeren u njihov interes. Stavio sam se u njihovu službu, spram njihova života i usmjeravajući se što sam bolje mogao na ono što ih zabrinjava. Način na koji bi to moglo ispasti moglo bi uzeti mnogo različitih varijanti raspona moje prisutnosti i pozornosti te moje obuke, kao i moju oplemenjenu, usavršenu, kultiviranu intuiciju, spontanost i senzibilitet.« (Mullan 1995, 328)

Kolegica, škotska psihijatrica Isobel Hunter-Brown, tijekom godine dana Laingova mlađa kolegica-studentica u Glasgowu (iako su imali iste profesore), preispitala je Laingov rad u svojoj kritičkoj knjizi $R$. D. Laing $i$ psihodinamska psihijatrija u Glasgowu 1950-ih (2007). U njoj razmatra škotske psihijatrijske i psihoterapijske tradicije, koje su oblikovale njen i Laingov osnovni profesionalni stav. Laing, kao humanist i suosjećajan psihoterapeut, ne samo da je dao glas prijateljima koji su patili nego je i svoju nepodijeljenu pozornost posvetio i onima koji su postali njegovi pacijenti. Laingove su ideje duboko ukorijenjene u profesionalnom pristupu ljudi kao što je, primjerice, psihodinamski pogled njihova pokojna profesora Fergusona Rodgera. Psihoanalitičar Tom Freeman poslužio je kao uzor za Lainga:

»Osobni ljudski pristup koji je Laing propovijedao kao da je njegov, prožima Škotsku školu kakvu sam ja poznavao.« (Mullan 1995, 28)

Pacijenti su tretirani kao osobe. Pacijentova ekspresija njegove bijede facilitirana je potpornom psihoterapijom u bolnici Gartnavel Royal pedesetih godina prošlog stoljeća. Liječnici i medicinske sestre provodili su ideal razumijevanja pacijenata i maksimizirali njihov potencijal. Ovaj "personalistički« pristup pacijentu ponudio je inicijativu. Mlađi liječnici, kao što su Hunter-Brown i Laing (tada star 26 godina), učili su prema modelu naukovanja (šegrtovanja), kao što su to činili i Laingovi studenti 1970-ih. Zadatak je bio naučiti »vidjeti«, »čitati« i osjetiti značenje ponašanja i smisla u doživljavanju drugog kao drugog, vjerovati vlastitoj intuiciji, prakticirati razgovor s nesvjesnim i uvijek tražiti pacijentovu motivaciju i psiho-dinamičko razumijevanje simptoma, u svjetlu njihova života i društveno-kulturnog konteksta. Škotska psihijatrija iznijela je ideju da kod psihičke bolesti i interakcije etiologiju treba tražiti među pacijentovim osobnim čimbenicima, od ustroja i ranog iskustva, i okolišnim, interpersonalnim i kulturnim (Hunter-Brown 2007, 93). 
Jednom je Laing došao u London izraziti vlastitu varijaciju ovog škotskog psihoterapijskog pristupa. Ono što je prije svega bilo važno, bio je vlastiti pogled na bolesnika. U svim Laingovim prikazima slučajeva - od The Divided Self (1960.) do The Voice of Experience (1982.) - ovo je postalo njegovo stanje umjetnikovanja, prikazujući moduse pacijentova »bivanja-u-svijetu«. Govor, ponašanje, iskustvo, geste i druga neverbalna komunikacija uvijek se smatraju »smislenima u u kontekstu životne situacije bolesnika. Budimo vješti u uspostavljanju kontakta s veoma povučenim pacijentima, empatično odražavajući bilo kakve njihove geste. Način na koji »vidimo« iskustvo i ponašanje naših pacijenata, sposobnost da »vidimo« kako pristupamo "promatranju« $\mathrm{i}$ konstruiranju onoga što se zapravo događa s tom osobom, svjesno i nesvjesno utječe na to kako ćemo nju ili njega liječiti.

\section{Iskustva su činjenice}

Iskustvo je osnova svake korisne teorije o socio-fenomenologiji osoba. Teorija određuje kako gledamo na ljude, kako pristupamo ljudima, kako o njima razmišljamo te kako o njima (nama) razgovaramo među sobom. Način na koji ljudi bivaju »tretirani« rezultat je teoretske pozicije koju ne treba samo internalizirati kao ulazne podatke već ih percipirati fluentno - kao izlazne. Kada takvu teoriju »primijenimo« na ljude, mi se u našoj najnježnijoj, najhumanijoj maniri putem takvih postupaka vodimo kao »bihevioralnom modifikacijom«. Svrha je terapije odvući ponašanje iz te vrste kontrole (trebao sam misliti), a ne je učiniti učinkovitije kontroliranom tehnologijom (Laing 1976, 113). Cilj je psihoterapije promjena, a ne prilagodba ili prijevara. Danas idemo na otpornost i samoosnaživanje. U The Divided Self, svojoj prvoj knjizi koju je napisao u dobi od 33 godine, Laing predstavlja praktični program hermeneutičkog razumijevanja psihoze, koristeći metodu egzistencijalne, međuljudske fenomenologije. Laing je pokušao opustiti napetu situaciju između psihijatra i pacijenta. Već je 1950-ih napisao koliko je za nas kao profesionalce važno da smatramo kako ova situacija nije »znamo što se događa, ali pacijent ne zna«. To je prije »ipak mislim da shizofreničari imaju više za podučavanje psihijatara o njihovim unutarnjim svjetovima nego što psihijatri moraju podučavati svoje pacijente«. Osoba koja prolazi kroz psihotičnu epizodu često u nama, ljudima izvana, budi osjećaj da oni »ne dopuštaju zvukovima svijeta da prodru u svijet njihova bića«. S Laingom dobivamo prvi prikaz iskustva. Zatim, postoje opisi tih prikaza. Objašnjenja se temelje na pisanim opisima, istražujući što subjektivni slučaj predstavlja za uključenu osobu. Tada je napravio prvi ad hoc teorijski odraz ovih »podataka«. Naše iskustvo njegova ili njezina ponašanja i naše ponašanje kao odgovor na naše iskustvo osnova su Laingove teorije. U svrhu približavanja slici u The Divided Self ponudio je skupove parova:

1. ontološka sigurnost nasuprot ontološke nesigurnosti;

2. otjelovljeno (Utjelovljeno?) nasuprot neotjelovljenog (neutjelovljenog?) Sebstva;

3. unutarnje Sebstvo nasuprot »vanjskog« Sebstva;

4. sistem lažnog-sebstva nasuprot sistema istinskog-sebstva;

5. samosvijest i drugotna svijest.

Ovo je praćeno modusima interpersonalnih iskustava, koja su prikazana u našim primijenjenim oblicima interpersonalnih djelovanja. Laingov je cilj bio »učiniti ludilo i proces ludovanja razumljivim«. Jasno je identificirao dehu- 
manizirajuće posljedice biološke psihijatrije (njezine modele, tehnike i ideologije) u tretiranju osoba kao neispravnih bioloških mehanizama. Laing je svoje pacijente slušao kao osobe i podredio svoje vrijeme stvaranju humanog i osobnog odnosa s njihovim iskustvom, provodeći istraživanja na Tavistockovu institutu za ljudske odnose, usmjeren na proces interakcije i prakse (djelovanja), posebno u obiteljima i brakovima s iskustvima psihoze. Istraživanjem je htio saznati u kojoj je mjeri ludilo razumljivo.

U svrhu testiranja teorije dijalektičke inteligibilnosti (novi eksperimentalni tretman), osnovao je 1965. godine terapijsku zajednicu Kingsley Hall. U praksi življenja postoji »biti po sebi«. U društvenom procesu postoji »biti u sebi«. Praksa obično vodi do pitanja: što je učinjeno?. S druge strane, proces dovodi do pitanja: što se događa? Rezultate svojih istraživanja stavio je u službu onih ljudi koji su tada još bili označavani kao »mentalno bolesni«, pozajmljujući im svoj stručni glas u vlastitim anti-stigmatskim publikacijama, u kojima se zalagao za oporavak duševnih patnji svojim oštroumnim, poznatim i elokventnim riječima. Godine 1965. osnovana je Philadelphijska udruga i Laingova prva terapijska zajednica u Kingsley Hallu. U to su vrijeme Laing i njegovi kolege proveli pet godina kao sudjelujući promatrači. Nakon toga, osnovana su druga kućanstva Philadelphijske udruge. Kasnih sedamdesetih godina postojalo je osam kuća u kojima je najčešće spavalo osam osoba, jedna u Londonu i jedna u Oxfordu, u kojima se razvijalo daljnje učenje iz iskustvenog istraživanja u Kingsley Hallu. Tamo sam odradio terenski rad u trajanju od devet mjeseci, od rujna 1976. do lipnja 1977. godine.

\section{Psihoterapija, poseban oblik drugarstva}

Uobičajeni čimbenici u modernoj psihoterapiji dokazuju u velikoj meta-analizi koju su proveli Assay i Lambert (1999). Pokazuju sljedeće empirijske dokaze o tome što funkcionira u svim oblicima terapije:

- metode i čimbenici koncepta $15 \%$;

- očekivanja i placebo efekti $15 \%$;

- psihoterapijski odnos $30 \%$;

- faktori pacijenta i ekstra-terapijske promjene $40 \%$.

Što ovi rezultati znače za pacijente i psihoterapeute? Promjena koja vodi ozdravljenju leži u interakciji među ljudima jer se ljudi ne mijenjaju izolirano iznutra. Sporednu ulogu igra prakticiramo li psihoterapiju, kognitivnu bihevioralnu terapiju, psihoanalizu ili tjelesnu psihoterapiju. Najvažnija je stvar u psihoterapiji terapijski odnos te životni kontekst i obrazovanje pacijenta. Ono što je podijeljeno zapravo pripada zajedno. Imamo sve dualnosti unutarnjeg i vanjskog, privatnog i javnog, bivanja i ne-postojanja, istinitog i lažnog itd. Govorimo o pozornosti nasuprot usamljenosti. U Švicarskoj je ovaj model liječenja dobro poznat kroz Soteriu u Bernu. Institut je osmislio i u uspjeh pretvorio socijalni psihijatar Luc Ciompi, koji ju je koncipirao na Soteria-Californiji s Lorenom Mosherom. ${ }^{1}$ Vanjski čimbenici i odvojene socio-kulturne situacije (kao što su stanovanje, obrazovanje, rad, financijska situacija i prijatelji) najučinkovitiji su momenti uspješnog liječenja.

Ono što je Laing prakticirao bila je neka vrsta bio-terapije ili realnosne terapije: neke od njih možete nazvati psihoanalitičkima, neke egzistencijal-

Za više vidi: http://www.soteria.ch/ (pristup-

ljeno 12. 12. 2018.). 
nima, neke od njih Gestalt, neke eklektičnima, neke psiho-sintezama, neke primarnima - svi ti mali dijelovi i komadići bili su fragmenti cjelovitog niza mogućnosti, uključujući i terapiju stvarnošću (Mullan, 1995, 326-327). To je bio trenutak u Laingovu eksperimentu umjetnosti liječenja, u kojemu je pokušao ukloniti fiksne uloge; prakticirao je tehniku ne imanja tehnike iscjeljivanja; demistificirajući mitonosce; pokušavajući suzbiti življenje s druge strane zdravog razuma. The Voice of Experience je Laingov kasni terapijski i epistemološki credo. Psihoanalitički, pripadao je nezavisnoj skupini Britanskog psihoanalitičkog pokreta. Tamo je saznao koliko je važna podudarnost između pacijenta i terapeuta. Za funkcioniranje psihoterapije mora postojati odgovarajuća podudarnost. Dopustite da kao ilustraciju navedem slučaj koji je Laing prenio nama studentima.

\section{Terenske bilješke}

»Devetogodišnja djevojčica, koja je nekoliko mjeseci bila autistična, bila je u pratnji oca prilikom susreta s Laingom. Najednom, u sobi za savjetovanje, Laing reče ocu da se vrati za pedeset minuta. Djevojčicu su prethodno vodili odgojnom psihologu, dječjem psihoterapeutu i, naravno, dječjem psihijatru, ali ništa nije donosilo rezultata - dijete nije govorilo. Stoga su je roditelji odveli k ovom poznatom psihoanalitičaru kako bi ga isprobali kao svojevrsnu posljednju instancu, prije nego li bude primorana otići u kliniku. Kad je otac otišao, Laing je udobno sjedio u svojem stolcu, a djevojci koja je stajala usred sobe rekao je: 'Ne moraš ništa učiniti. Ne moraš razgovarati sa mnom, ne moraš nastupati, samo ostani samnom 50 minuta, dok ja ostanem s tobom, pa ćemo vidjeti što će se dogoditi, stoga se samo opustimo'. Shvatio je da djevojka prihvaća njegove riječi. Polako je počela hodati prema njemu s rukama podignutim paralelno pred sobom. Dlanovi njezinih ruku bili su okrenuti prema Laingu. Podignuo je ruke uvis, kako bi je zrcalio, i primio njezine ruke ako bi tako željela, i zatvorio oči. Ništa nije rečeno. Laing je dodirivao njezine ruke, dok je ona dodirivala njegove. Slijedio je njezine usporene pokrete, kružeći gore i dolje, unutra i van. Djevojka se tako igrala s njim, a on se pridružio kroz veći dio vremena od pedeset minuta. Kad je došlo vrijeme da se otac vrati pokupiti djevojku i platiti Laingu što ga slijedi, otac je bio malo iznenađen. Nevoljko je platio 70 funti (poprilično veliku svotu u ranim 1970-im) i otišao. Laing je tada zaboravio na djevojku. Jedne večeri, sredinom 1980-ih, dok se opuštao na zabavi, priđe mu mlada žena i predstavi se govoreći: 'Sjećaš li me se? Kao mlada djevojka došla sam te vidjeti na konzultacije?'. 'Ne', rekao je, 'ne mogu te se sjetiti. Koji je bio povod i situacija?'. Nastavila je: 'Ja sam bila ona autistična djevojka koja se igrala tvojim rukama'. Sinulo mu je i rekao je: 'Ah da, sada se sjećam. Uvijek me zanimalo što ti se poslije dogodilo'. Rekla je: 'Pa, moj otac je bio prilično namrgođen i pomalo ljutit na vas zbog visoke naknade; mrmljajući dok smo hodali prema automobilu. U jednom trenutku za vrijeme vožnje pitao me, još uvijek ljutitog raspoloženja, Što se dogodilo u ovoj skupoj sesiji? Što ste učinili s dr. Laingom?' Spontano sam rekla 'to se tebe ne tiče'. [Nasmijala se dok je govorila Laingu, a Laing se nasmijao dok je govorio nama] 'Isprva je to mog oca učinilo još nervoznijim dok iznenada nije shvatio da ponovno govorim.' "

Čarolija začaranog kruga habitué- $a$ bila je prekinuta. Umjetnost psihoterapije može nam pokazati kako iz našeg unutarnjeg Sebstva možemo naučiti kultivirati drugačije preživljavanje ove crvene niti u životu. Jednom kad to shvatimo imamo izbor. Svaki je uzorak navika koju je, kao što svi znate, vrlo teško promijeniti. Ipak, možemo istjerati staru naviku stavljajući novu na vlastitu putanju. Istraživanje u Sveučilišnoj bolnici Eppendorf u Hamburgu koristi konferenciju o liječenju, sustavnu obiteljsku terapiju temeljenu na rodoslovnim stablima, kao model integrativne skrbi. Ovo istraživanje pokazuje da optimizirano ambulantno liječenje, koje koristi osobno usmjerenu terapiju, daje bolje rezultate od standardne paradigme skrbi preuzete s platforme 1 . U ovom modelu, rodbina može prepoznati da ono što privremeno uznemirena i uznemirujuća osoba u njihovoj sredini govori ima više smisla u kontekstu obitelji i njezinih transgeneracijskih pitanja no što se obično pretpostavlja. Istraži- 
vanje provedeno nad više od 100 obitelji koje su Laing i Esterson provodili u Londonu od 1959. do 1964. dokazalo je ovu teoriju prije pedeset godina. Pronalaženje puta iz suženja takozvanog »poremećenog i uznemirujućeg«, koji se kreće prema ponovnom ozdravljenju i cjelovitosti, stoji u središtu tog navođenog procesa.

»Čemu sve ovo?«, moglo bi biti pitanje koje prošlo iskustvo otvara sadašnjosti i budućnosti. U mnogim slučajevima radi se o određenom razvoju, pronalaženju pojedinčeva vlastita puta u životu, uglavnom pod posebno teškim uvjetima unutarnje i vanjske disharmonije, a ponekad (u gotovo četvrtini slučajeva) traume zlostavljanja (nasilne, seksualne, emotivne). Često se javlja početni gubitak, kada se odustane od sukoba između unutarnjeg svijeta osobe i vanjske stvarnosti (istinsko Sebstvo i lažni sustav Sebstvo). Pronalaženje osobnog jedinstva u njihovom vlastitom društvenom biću je teško i bolno je prepoznati koliko su pali daleko od života da bi došli do »ne mogu ići dalje« trenutka. Ne postoji ništa strašnije od terapeutskog profesionalca koji je izgubio kontrolu nad drugim, ali ne i nad vlastitom tjeskobom. Aporija Psihe čini je jasnim; nema potrebe da je se bojimo. Psihosocijalne intervencije - a postoje i empirijski dokazi za to (Read, 2013) - prikladniji su za liječenje psihičkih poremećaja i patnji na siguran način, bez izazivanja oštećenja, nego ona »lijekovima« farmakološkog podrijetla. Kada um pati potrebna je promjena staze, daleko od pesimističke ideologije koju promovira biološka psihijatrija i kemijska industrija, prema humanom pristupu iscjeliteljske umjetnosti poput one Eshilove, koja se prakticira tisućama godina, ali koja je također moderna i na temelju dokaza. The Voice of Experience i Nova politika iskustva pjevuše melodiju našeg uvjetnog, vremenskog i ograničenog života. Freud je većma vidio teorijske (i druge) zablude kao pokušaje popravljanja prekida sa stvarnošću. Laing ih je zamišljao kao poruku za proces samoozdravljenja koji čezne za sigurnim osjećajem Sebstva. U terapiji uvijek postoji prostor za osobnu slobodu i egzistencijalne izbore. Naša psihoterapijska zadaća je iznijeti vidljivost, čujnost i egzistencijalni identitet druge osobe koja traži naš savjet i pomoć. Naš vlastiti smisao za kontekst, ono što smatramo stvarnim i nestvarnim, mora biti jasan. Što čujem; koji je moj referentni okvir riječi, sintakse i sadržaja; koji su njezini referentni okviri? Kako da znam da »to shvaćam « i kako znamo da je ona ili on to shvatio? Naša umjetnost iscjeljivanja stoga je kultiviranje međuljudskih sposobnosti. Laingova glavna tema bila je bol života kao osobe koja nismo, dok je unutarnje ili istinsko Sebstvo isključeno ili ponekad ušutkano. Ipak, naša se odrasla otjelovljenje i snaga istinskog Sebstva (autentičnog života) ne mogu ušutkati. Ako ne slušamo dušu utjelovljenu u nama, to naše tijelo čini bolesnim. Moj san iscjeljenja ilustrira kako naši pacijenti i mi - aktivni u skrbničkim profesijama - možemo biti oslobođeni od ropstva vlastitog odgoja, obrazovanja i društvenog uvjetovanja, klasne svijesti i religijske pripadnosti. Možemo popustiti čvorove, razdvojiti nas od poistovjećivanja s onim što je bilo, i raširiti naš životni rep čiji labavi kraj istrajava u zlatnom sjaju.

U čijem svjetlu prakticiram? Želite li znati moj odgovor? Boginje Astarte, ženskog božanstva plodnosti. Drugi je nazivaju Ishtar ili Venera ili Afrodita ili žena u Isusovu obliku. Možemo se podsjetiti na slavensku božicu Vesnu. Sve koje imaju veze s otvorenom tajnom koja dolazi pod imenom: Ljubav. Druga strana »aporije psihe« jest Morana (Marzhana), u ovom okruženju - božica noći, zime i podzemlja i konačno kraj daha kao što to pojmimo mi smrtnici, nadolazeći pod imenom Smrt. 


\title{
Literatura
}

Assay, T. P.; Lambert, M. J. (1999): »The empirical case for the common factors in therapy: Quantitative findings «, u: Hubble, M. A.; Duncan, B. L.; Miller, S. D. (ur.), The heart and the soul of change: What works in therapy, American Psychological Association, Washington, str. 33-56.

Cameron, J. L.; Laing, R. D.; Mcghie, A. (1955): »Patient and nurse: effects of environmental change in the care of chronic schizophrenics«, The Lancet 269 (1955) 6905, str. 1384-1386. doi: https://doi.org/10.1016/S0140-6736(55)93182-2.

Hunter-Brown, I. (2007): R. D. Laing and Psychodynamic Psychiatry in 1950's Glasgow: A Reappraisal, Free Association Books, London.

Huxley, F. (1974): The Way of the Sacred, Aldous Books, London.

Itten T.; Roberts, R. (2014): The New Politics of Experience and the Bitter Herbs, PCCS Books, Monmouth.

Laing, R. D. (1982): The Voice of Experience: Experience, Science and Psychiarty, Allan Lane, London.

Laing, R. D. (1976): The Facts of Life: An Essay in Feelings, Facts and Fantasy, Pantheon Books, New York.

Laing, R. D. (1960): The Divided Self: An Existential Study in Sanity and Madness, Tavistock Publications, London.

Mullan, B. (1995): Mad to be Normal: Conversation with R.D. Laing, Free Association Books, London.

Read, J.; Dillon, J. (2013): Models of Madness, Routledge, London.

\section{Theodor Itten}

\section{The New Politics of Experience and R. D. Laing's Old "New Ideas"}

\begin{abstract}
The psychotherapeutic legacy of R. D. Laing and his new take on Scottish psychodynamic psychiatry, in whose heritage he practised - "the patients are like you and me" - are explored. His testimony of experience as a psychoanalyst and theoretician, within the field of so-called "anti-psychiatry", "radical psychiatry" and "avanti-psychiatry", with the anger and outrage expressed towards the impersonal nature of modern psychiatry, the malign influence of the pharmaceutical industry, the alienating character of modern university education, spanning from the mid 1960's to late 1980's, are critically elaborated. The focus of the New Politics of Experience on radical social thinking and interdisciplinary study is based on social phenomenological empirical research and the development of an integrative psychotherapeutic approach.
\end{abstract}

Key words

Ronald David Laing, aporias of psyche, New Politics of Experience, integrative psychotherapy 